\title{
Peningkatan Pengetahuan Masyarakat (dewasa) tentang Demensia dan Pengelolaannya terhadap Lingkungan Sosial di Palangka Raya
}

\author{
Nawan
}

\begin{abstract}
ABSTRAK
Kegiatan ini bertujuan untuk meningkatan pengetahuan tentang demensia dan keterampilan masyarakat untuk mengenal gejala demensia secara dini, mencegah, dan menangani demensia dalam lingkungan sosial (keluarga dan masyarakat). Metode yang digunakan adalah perencanaan partisipatif, pendekatan, dan kegiatan penyuluhan dengan evaluasi pretes dan postes. Hasil yang dicapai adalah peningkatan pengatahuan masyarakat tentang demensia dan keterampilan mengenal gejala demensia secara dini. Simpulannya adalah kegiatan ini berhasil mencapai tujuannya sehingga demensia dapat dicegah dan dikelola dengan baik oleh masyarakat.

Kata Kunci : demensia, pengetahuan, keterampilan.
\end{abstract}

\section{A. Pendahuluan}

Demensia merupakan kumpulan gejala (sindrom) akibat penyakit otak yang bersifat kronis atau progresif. Penyakit otak yang dimaksud adalah adanya gangguan beberapa fungsi kortikal yang lebih tinggi, termasuk memori, berpikir, orientasi, pemahaman, perhitungan, kapasitas belajar, bahasa, dan penilaian. Gangguan fungsi kognitif biasanya disertai dan kadang-kadang didahului oleh penurunan kontrol emosional, perilaku sosial, atau motivasi. Sindrom ini terjadi dalam sejumlah besar kondisi primer atau sekunder gangguan otak (WHO, 2012).

Sekitar 2\% sampai 10 \% kejadian demensia dimulai pada usia sebelum 65 tahun. Sedangkan prevalensi demensia pada usia di atas 65 tahun adalah dua kalinya (WHO, 2012). Beberapa faktor risiko terjadinya demensia pada usia pertengahan dan lanjut merupakan faktor risiko yang dapat dimodifikasi contohnya merokok, konsumsi alkohol, kegemukan, diabetes, hipertensi, dan hiperkolesterolemia. Faktor risiko tersebut dapat diterapi sehingga dapat mencegah terjadinya demensia. Faktor lain yang merupakan faktor risiko demensia yaitu faktor genetik contohnya familial autosomal dominant, penyakit Alzheimeres atau demensia frontotemporal, cerebral autosomal dominant arteriopathy with subcortical infarcts dan leukoencephalopathy [CADASIL], atau penyakit Huntington "es. Faktor genetik tersebut dapat dihindari dengan cara konseling pranikah (Fairbain et al, 2007).

Demensia mengakibatkan terjadinya keterbatasan (disability) pada usia lanjut sehingga dapat mempengaruhi kehidupan sehari-hari penderita demensia dan orang sekitar yang merawatnya. Penderita demensia sulit melakukan kegiatan ringan/biasa dalam kehidupan sehari-hari sehingga menjadi tergantung dengan orang yang merawat. Selanjutnya dapat mempengaruhi kesehatan, psikologi, dan emosi penderita demensia, orang yang merawat, dan keluarga penderita demensia (WHO, 2012).

Kurangnya pengetahuan dan kesadaran akan terjadinya demensia dapat memperparah demensia oleh karena terjadi keterlambatan diagnosis dan penanganan. Pada negara yang kurang perhatian terhadap demensia akan mengalami peningkatan angka kesakitan dan kematian penduduknya. Di Inggris, pembiayaan demensia menduduki peringkat pertama, lebih tinggi dari kanker dan penyakit kardiovaskular lain (Fernades et al, 2010). Terdapat beberapa cara untuk menangani demensia, tetapi yang terpenting adalah pemberian motivasi pada penderita demensia, orang yang merawat, dan keluarga penderita demensia (Alzheimer"es association, 2012, The Alzheimer Society of Ireland, 2011).

Di Palangka Raya terdapat masyarakat yang berpotensi mengalami demensia atau hidup dengan penderita demensia dan kurangnya pengetahuan masyarakat mengenai demensia. Oleh karena itu, kegiatan ini bertujuan untuk meningkatan pengetahuan tentang demensia dan 
keterampilan masyarakat untuk mengenal gejala demensia secara dini, mencegah, dan menangani demensia dalam lingkungan sosial (keluarga dan masyarakat). Akibatnya adalah menurunnya angka kejadian demensia dan meningkatnya kualitas hidup penderita demensia.

\section{B. Metode}

Metode pendekatan yang digunakan yaitu sebagai berikut.

1. Metode Perencanaan Partisipatif.

Metode pendekatan yang digunakan yaitu suatu kegiatan perencanaan yang melibatkan masyarakat untuk menumbuhkan rasa keingintahuan dari partisipan/anggota kelompok masyarakat. Pengumpulan data dasar dan informasi mengenai potensi kelompok masyarakat ini dilakukan melalui survei. Pada tahap ini dilakukan pendekatan- pendekatan dan penyamaan persepsi dengan berbagai unsur dalam masyarakat menyangkut potensi kelompok. Data dasar yang dimaksud adalah keadaan sosial budaya dan ekonomi masyarakat, potensi sumber daya manusia, dan sarana prasarana pendukung.

2. Pendekatan terhadap tokoh masyarakat untuk mendapatkan dukungan secara penuh karena peranan para tokoh tersebut terhadap anggota kelompok secara umum .

3. Kegiatan, meliputi antara lain:

- Penyuluhan (mengenai demensia, faktor risiko, dan penanganan demensia; cara mengenali gejala demesia; cara mengenali faktor risiko demesia; cara mencegah demensia; dan cara menangani/mengelola demensia dalam lingkungan sosial (termasuk keluarga dan masyarakat).

- Evaluasi dilakukan dengan cara diuji pre dan post test setelah mendapatkan pengetahuan mengenai demensia, faktor risiko, dan penanganan demensia.

\section{Hasil dan Pembahasan}

Peserta yang hadir dalam kegiatan ini terdiri dari 2 kelompok dewasa yaitu kelompok wanita dan pria. Kelompok pria berjumlah 16 orang (dengan rerata usia 54 tahun) dan kelompok wanita berjumlah 24 orang (dengan rerata usia 47 tahun). Kelompok sasaran telah memenuhi target usia, yaitu dewasa (di atas $>25$ tahun), memasuki masa yang rawan mengalami masalah kesehatan akibat usia lanjut (degenatif). Kelompok usia ini juga sering berhubungan dengan orang usia lanjut (>65 tahun) dengan gejala demensia (pikun), misalnya orang tua atau pasangan hidup (suami/isteri).

Hasil evaluasi pretes dan postes pada kedua kelompok ditampilkan pada tabel berikut.

Tabel 1. Pengetahuan kelompok pria dan wanita tentang demensia

\begin{tabular}{|l|l|l|l|l|l|l|l|}
\hline \multirow{2}{*}{ No. } & \multicolumn{1}{|c|}{ Pertanyaan } & \multicolumn{2}{c|}{ Pretes (\%) } & \multicolumn{2}{c|}{ Postes (\%) } & \multicolumn{2}{c|}{ Peningkatan (\%) } \\
\cline { 3 - 8 } & & Pria & Wanita & \multicolumn{1}{c|}{ Pria } & Wanita & \multicolumn{1}{c|}{ Pria } & Wanita \\
\hline 1. & $\begin{array}{l}\text { Apakah Anda tahu } \\
\text { definisi/pengertian } \\
\text { demensia/pikun? }\end{array}$ & 2 & 5 & 100 & 100 & 100 & 95 \\
\hline 2. & $\begin{array}{l}\text { Apakah Anda tahu } \\
\text { penyebab terjadinya } \\
\text { demensia/pikun? }\end{array}$ & 2 & 5 & 100 & 100 & 100 & 95 \\
\hline 3. & $\begin{array}{l}\text { Apakah Anda tahu } \\
\text { tanda dan gejala } \\
\text { demensia/pikun? }\end{array}$ & 87 & 83 & 100 & 100 & 13 & 17 \\
\hline 4. & $\begin{array}{l}\text { Apakah Anda tahu } \\
\text { faktor risiko terjadinya } \\
\text { demensia/pikun? }\end{array}$ & 25 & 42 & 100 & 100 & 75 & 58 \\
\hline
\end{tabular}




\begin{tabular}{|l|l|l|l|l|l|l|l|}
\hline 5. & $\begin{array}{l}\text { Apakah Anda tahu } \\
\text { bagaimana } \\
\text { penanganan/pengelolaan } \\
\text { demensia/pikun? }\end{array}$ & 0 & 4 & 100 & 100 & 100 & 96 \\
\hline 6. & $\begin{array}{l}\text { Apakah Anda tahu } \\
\text { pengaruh } \\
\text { demensia/pikun } \\
\text { terhadap lingkungan } \\
\text { sosial? }\end{array}$ & 37 & 42 & 100 & 100 & 63 & 58 \\
\hline
\end{tabular}

Keterangan : Nilai pretes dan postes adalah jumlah peserta yang menjawab pertanyaan dengan benar.

Dari tabel 1 didapatkan hasil bahwa terjadi peningkatan pengetahuan kelompok wanita dan pria tentang demensia. Pengetahuan tersebut terdiri dari :

1. Definisi demensia, yaitu kumpulan gejala (sindrom) akibat penyakit otak yang bersifat kronis atau progresif.

2. Penyebab terjadinya demensia, yaitu adanya gangguan beberapa fungsi kortikal yang lebih tinggi, termasuk memori, berpikir, orientasi, pemahaman, perhitungan, kapasitas belajar, bahasa, dan penilaian.

3. Faktor risiko terjadinya demensia, yaitu usia (> 65 tahun), penyakit faktor risiko yang dapat dimodifikasi contohnya merokok, konsumsi alkohol, kegemukan, diabetes, hipertensi, dan hiperkolesterolemia, faktor genetik contohnya familial autosomal dominant, penyakit Alzheimeres atau demensia frontotemporal, cerebral autosomal dominant arteriopathy with subcortical infarcts dan leukoencephalopathy [CADASIL], atau penyakit Huntington "s.

4. Penanganan/pengelolaan demensia, yaitu pemberian motivasi pada penderita demensia, orang yang merawat, dan keluarga penderita demensia. Motivasi dapat diberikan berdasarkan pendekatan ilmu kesehatan kepada masyarakat yaitu lanjut usia sehat dan mandiri dan dari pendekatan sosiologi agama.

5. Pengaruh demensia pada lingkungan sosial, yaitu pada negara yang kurang perhatian terhadap demensia akan mengalami peningkatan angka kesakitan dan kematian penduduknya, mempengaruhi kesehatan, psikologi, dan emosi penderita demensia, orang yang merawat, dan keluarga penderita demensia.

\section{Simpulan dan Saran}

Simpulan yang didapat yaitu terjadinya peningkatan pengetahuan kelompok wanita dan pria tentang definisi demensia, penyebab demensia, faktor risiko demensia, penanganan/pengelolaan demensia, dan pengaruh demensia pada lingkungan sosial.

Saran yang diberikan yaitu perlunya diadakan kegiatan rutin pemberian informasi mengenai pencegahan demensia, pelatihan deteksi dini terhadap demensia, dan deteksi faktor risiko demensia melalui pemeriksaan kesehatan rutin. 


\section{Daftar Pustaka}

Alzheimer"s Association, 2012, Alzheimer"s Disease Facts and Figures, Alzheimer"s and Dementia Vol 8 Issue 2.

Fernadez RL, Leal J, Alastair, 2010, Dementia 2010, The Economic burden of Dementia and Associated Research in united Wisdom.

The Alzheimer Society of Ireland, 2011, Living With Dementia, The Alzhiemer Society of Ireland.

The British Psychological Society and Royal College of Psychiatrist, 2007, Dementia The Nice Scie Guidline in Supporting People with Dementia and Their Caressin Health And Social Care, National Clinical Practice Guidline Number 42.

World Health Organization, 2012, Dementia A Public Health Priority, World Health Organization.

Edhag O, Eklund HA, Almkvist O, 2008, Dementia - Caring, Ethics, Ethnical and Economical Aspects A Systematic Review. Volume 3. The Swedish Council on Technology Assessment in Health Care.

\section{Biodata Penulis}

Nama

Pekerjaan

Raya Bidang Keahlian

Alamat Institusi
: dr. Nawan, M.Ked.Trop

: Dosen Fakultas Kedokteran Universitas Palangka

: Kedokteran Tropis

: Jl. H. Timang Kompleks Tunjung Nyaho

Palangka Raya Kalimantan Tengah. 